\title{
Archaeological Testing and Recommendations for the Kennedy Bluffs Site, 41BP19, in Bastrop County, Texas
}

Glenn T. Goode

Follow this and additional works at: https://scholarworks.sfasu.edu/ita

Part of the American Material Culture Commons, Archaeological Anthropology Commons, Environmental Studies Commons, Other American Studies Commons, Other Arts and Humanities Commons, Other History of Art, Architecture, and Archaeology Commons, and the United States History Commons

Tell us how this article helped you.

This Article is brought to you for free and open access by the Center for Regional Heritage Research at SFA ScholarWorks. It has been accepted for inclusion in Index of Texas Archaeology: Open Access Gray Literature from the Lone Star State by an authorized editor of SFA ScholarWorks. For more information, please contact cdsscholarworks@sfasu.edu. 


\section{Archaeological Testing and Recommendations for the Kennedy Bluffs Site, 41BP19, in Bastrop County, Texas}

\section{Licensing Statement}

This is a work produced for the Texas Department of Transportation (TxDOT) by the report producer. TxDOT and the report producer jointly own all rights, title, and interest in and to all intellectual property developed under TXDOT's contract with the report producer. The report may be cited and brief passages from this publication may be reproduced without permission provided that credit is given to both TXDOT and the report producer. Permission to reprint an entire chapter, section, figures or tables must be obtained in advance from either the Supervisor of the Archeological Studies Branch, Environmental Affairs Division, Texas Department of Transportation, 125 East 11th Street, Austin, Texas, 78701 or from the report producer. 


\section{ARCHAEOLOGICAL TESTING AND RECOMMENDATIONS FOR THE KENNEDY BLUFFS SITE, 41BP19, IN BASTROP COUNTY, TEXAS}

B y

Glenn T. Goode

Texas

State Department of Highways and Public Transportation

Highway Design Division July 1984 
INTRODUCTION

Archaeological Site 41BP19 was reported by Daymond Crawford of the State Department of Highways and Public Transportation (SDHPT) Archaeology Section in November 1983, with a recommendation for test excavation. Testing was conducted by Glenn T. Goode of the SDHPT Archaeology Section and four employees of the local SDHPT office during the period May 7 through May 24, 1984. An estimated 70 persondays were expended during the field work on this project. Testing was conducted in accordance with Procedures for the Protection of Historic and Cultural Properties (36 CFR, Part 800), procedures prescribed and endorsed by the Federal Highway Administration. The testing objective was to determine eligibility for nomination to the National Register of Historic Places as prescribed by law. 
ARCHABOLOGICAL BACKGROUND

The term "transitional zone" (Kelley 1955), in reference to an area of cultural interaction, has long been used to describe the area separating eastern and coastal Texas from Central Texas. Recent studies have more or less adopted "transitional zone" in assessing cultural manifestations of the area (Prewitt 1974; Skelton 1977; Fullem 1977; Nightengale and Jackson 1983).

Skelton (1977) reports on several upland sites representing "temporary intermittently occupied work camps." He states that typological comparisons "suggest that the area was being used by cultural groups from different geographic areas." Namely, similarities exist with materials from Central, eastern, and coastal Texas. While suggesting that the peripheral cultural areas account for the similarities, Skelton (1977: 123) does not "rule out the possibility for an intermediate cultural area with distinctive local adaptations."

According to Fullem (1977), Archaic projectile points from the Black Hopper Site (41FY25) illustrate the mixture of traits "expected from an exchange among the three coterminous cultural areas--central, east, and coastal." Fullem further states that Central Texas influence is greatest, with substantial influence from adjoining areas. A quantification, admittedly subjective, of the degree and direction of nonlocal cultural influence produced these figures: 54\% Central Texas; 16\% East Texas; 29\% other/mixed attributes. The apparent blending of stylistic patterns is considered an Archaic phenomenon.

On the north side of Cedar Creek opposite 41FY25 is the Sand Burr Site, 41FY135, excavated in 1979 (Young 1979). Relatively deep but poorly stratified sandy deposits produced the largest artifact inventory thusfar excavated in the area. A 11 periods of cultural prehistory are represented, most by impressive numbers and diversity. 
Several other surveys and test excavations have been conducted since 1977. Brown and Kenmotsu (1980) tested two prehistoric sites, 41FY65 and 41FY178, in Fayette County and one in Bastrop County, 41BP176. The limited artifact inventories contained Fresno and Scallorn arrowpoints. A survey of Camp Swift (Skelton and Freeman 1979) located 42 prehistoric sites. Test excavations at eight produced limited amounts of material, including two Late Archaic dart points.

At Powell Bend (Kenmotsu, Bement, and Robinson 1982) 30 prehistoric sites were discovered, and testing uncovered hearths at 41BP191 and 41BP192. Recently completed (October 1983) excavation of 41BP191 produced numerous hearth and pit features with a small inventory of Archaic and Neo-American artifacts (Leland C. Bement, personal communication). In the Cummins Creek Prospect (Nightengale and Jackson 1983), the study area is described as a transitional zone between East, coastal, and Central Texas, with the major influence derived from Central Texas. Here, using Robinson's (1982) prehistoric settlement model, 56 prehistoric sites were recorded--relating types of sites to physiographic zones.

Three sites were excavated in the Allens Creek Project (Hall 1981). Among these, the Ernest Witte Site, 41AU36, produced more than 200 burials and abundant evidence of a widespread trade network in Late Archaic times.

Four sites within a two-mile stretch of State Highway 71 in Fayette County were investigated by Goode (1983, 1984). Sites 41FY 98 and $41 F Y 422$ produced cultural material of Early Archaic through Neo-American age. Intact hearths were found at both sites. These appeared to be related to the most abundantly represented components at both sites, of Late/Transitional A rchaic age.

A 11 known periods of cultural prehistory are represented in the study area: Paleo-Indian, Archaic, and Neo-American or Late Prehistoric. A division of the Archaic Stage into Early, Middle, Late, and Transitional Periods, a scheme long in use in Central Texas and employed by Skelton (1977) a the 
nearby Fayette Power Project, will be used. More recent and detailed chronologies by Weir (1976) and Prewitt (1982) were developed in Central Texas and are of only limited utility here. However, occasionally it will be necessary to address these for comparative purposes, or to clarify relationships of cultural periods. 


\section{THE STUDY AREA AS A CULTURAL TRANSITION ZONE}

The study area lies within a physiographic vegetational province known as the Post Oak Savannah which, combined with the Blackland Prairie, forms a long geographic belt separating Central, Eastern, and Coastal Texas. These physiographic zones occur in alternate bands in the southern and central regions, with the Post Oak Savannah representing the greater area. They divide into two distinct zones in the north, with the Blackland Prairie covering the wider expanse. To the west the Blackland Prairie joins the Central Texas hill country; to the east the Post Oak Savannah borders the forests of the East Texas Pineywoods.

Within these bordering regions existed prolific Archaic and Neo-American cultures whose remains are abundant and relatively well documented. By its dimensions and location the study area is a natural transition zone, both ecologically and culturally. Averaging some $170 \mathrm{~km}$ in width and bounded on all sides by regions supporting strong cultures, the study area absorbed cultural diffusion from several directions. The immediate study area is defined as the central region of the Post Oak Savannah, but discussion will also address broader regional developments.

Archaeologically, this "transition zone" (Kelley 1955). can be divided into three apparent but undefined regional units. Divisions are based upon varying cultural elements which are regionally distinctive but are as yet only vaguely understood.

The northern region is represented by excavations in the Upper Navasota and Lake Limestone region (Prewitt 1974; Mallouf 1979). Cultural complexes of north and northeast Texas occur within the northern limits of the same physiographic zones, but these lie outside the study area. Recognized cultural influences are predominately North-Central and East Texas in origin, with Central Texas represented. Prewitt's (1974) assessment of stylistictraits indicates greater Central Texas influence in the Early Archaic but little 
thereafter, with gradually increasing East Texas influence continuing into the post-Archaic or Neo-American Stage. Due to limited knowledge of the area, no statement regarding the significance of local cultural developments is made. It is stated that "the area experienced influences of varied intensity from East Texas and Central Texas while the geographical locations of the sites suggest a reasonably stable resource base" (Prewitt 1974). In fact, the frequency, distribution, and age of sites indicate that a stable resource base existed throughout the study area.

Some Archaic projectile point types representative of the region are Axtell, Neches River, Yarbrough-like, Dawson, and Godley. Other types occurring less frequently or primarily of non-local origin are Wells, Morrill, Yarbrough, Gary, and Darl.

The central region of the study area, in the Post Oak Savannah, is represented by excavations at Lake Somerville (Peterson 1965) and by several projects in the La Grange area (Fullem 1977; Skelton 1977; Young 1979; Nightengale and Jackson 1983; Goode 1983, 1984). In Fayette County along Cedar Creek both Fullem and Skelton indicate that Central Texas influence is greatest and that other areas contributed in undetermined or varying degrees. No mention is made of traits that could be local in origin.

Recent excavations by Goode (1983, 1984) at Sites 41FY98, 41FY422, and 41BP19, and examinations of local artifact collections permit some general statements regarding indigenous Archaic cultural development. In the Early Archaic, projectile point styles typical of adjacent areas such as Central and East Texas are widespread in the study area, but in much reduced numbers. The more commonly seen types include Angostura, Uvalde-like, Andice, Bell, Big Sandy-like, and similar side-notched forms from the east. Equally widespread, and in the majority at some sites, are lanceolate and stemmed forms of apparent local origin. These forms are unlike the established types of adjacent regions and occur in sufficient numbers to suggest the presence of a resident population. The stemmed forms, corner and basally notched, likely are coeval with such Central Texas types as Gower, Uvalde, and Martindale. 
The Baird/Taylor type is also seen occasionally and appears to be the 1 ast relatively common Central Texas type until Pedernales appears some 1500 years later. If this occurrence proves to be correct, decreased Central Texas influence after the Early Archaic would coincide with Prewitt's (1974) analysis of the northern region. The Pedernales type is widespread, occurring as the lone Central Texas type at some sites. Frequently the Pedernales points have wide, thin blades, traits common to the type in Central Texas but often lacking along fringe areas of the region. The wide, thin blades and keen but dulled edges indicate that there, as in Central Texas, Pedernales bifaces frequently were used as knives. The relative frequency of this type in the study area could be related to an hypothesized time of population increase in Central Texas, the Round Rock Phase (Weir 1976).

Including Pedernales, projectile point styles typical of the Middle and Late Archaic Periods are, as in surrounding areas, a variety of straight, contracting and expanding stem forms. General similarities exist between local assemblages and such types as Bulverde, WIlliams, Lange, M arcos, M orrill, Yarbrough, Gary, and Kent. Most of these types are not common in the study area, however, and most similarities perhaps merely reflect widespread trends in projectile point technology.

The southern region of the study area has experienced less archaeological work, and only very general observations are possible. Two investigations near the southern limit of the Post Oak Savannah are the Cuero Reservoir Survey (Fox et al. 1974) and the Berclair Site (Hester and Parker 1970).

Notable at the Berclair Site was a Toyah Phase occupation with great similarity to the Toyah of Central Texas.

A number of projectile point styles common to the central region, particularly Darl and Ensor-like, continue into the southern region, with fewer straight and contracting stem forms that resemble East Texas material. Observations of DeWitt and Lavaca County collections indicate close ties with Archaic cultures of the coastal plain in Victoria and Jackson Counties. A 
representative amount of Morhiss material is present in the area. To some extent Central Texas influence follows trends noted in the central region.

Three major projects of the coastal plain, a 11 less than $40 \mathrm{~km}$ from the Post Oak Savannah, are the Morhiss Site, Palmetto Bend Reservoir (McGuff 1978), and Allens Creek (Hall 1981). Allens Creek, near the eastern limit of the Post Oak Savannah and only $85 \mathrm{~km}$ southeast of the study area, produced an impressive array of Middle, Late, and Transitional Archaic artifacts. Apart from the Late/Transitional Archaic types, Ensor/Fairland and Godley, the most common forms have straight and contracting stems. Some of these, Gary and Kent, are related to the East Texas Archaic; but a majority could be of local origin, possibly somewhat influenced by East Texas styles, and are similar to forms common in the Post Oak Savannah. Central Texas influence among dart point forms is minor.

It should be expected that East Texas influence would be greatest in the adjacent Post Oak Savannah, some forested areas of which are quite similar to the eastern woodlands. Central Texas influence predominates in the Blacklamd Prairie and is particularly evident in the southern and central regions of the Post Oak Savannah as well.

Despite the widespread evidence of outside influence, it is hypothesized that, beginning not later than the Middle Archaic, an indigenous population with distinctive cultural traits became established in the study area. In fact, recent excavation (including nonprofessional excavation) at the Kennedy Bluffs Site, reported herein, indicates that an indigenous population was already established in Early Archaic times. Here, in a stratified deposit, were found hearths and numerous lanceolate bifaces--some of the Angostura type but most representing a local or regional specialization. Evidence of indigenous cultural development is found in the abundance and variety of Middle Archaic projectile point styles. Accompanying this development is an apparent decrease in Central Texas material, further indication, perhaps, of an established cultural tradition. 
Diagnostic projectile points of the period are primarily straight and contracting stem forms, diverse and untyped, comparable to similar forms of adjacent areas. Included in the assemblage are types derived from Central and East Texas, but in a clear majority are those specimens with distinctive traits, or which bear only a vague resemblance to nonlocal styles.

The diversity of Middle Archaic forms continues into the Late Archaic in which expanding stem forms predominate. Various forms of local origin are in the majority, but there is continued or increased influence from Central Texas at this time. The Central Texas diagnostics--Castroville, Marshall, and $M$ arcos-like of the San M arcos Phase (Weir 1976)--are most commonly found. The presence of these forms may be an expression of the hypothesized population increase noted by Weir (1976) and Hall (1981). Quoting Hall (1981:302), "Expanding Late Archaic and Woodland populations in Texas. . resulted in greatly improved systems of communication and transport." Evidence of such transport or trade occurs at the Ernest Witte Site, $70 \mathrm{~km}$ southwest of Houston. Some of the Late Archaic artifacts at the Ernest Witte Site are of Central Texas origin, having passed through the study area to their destination. Notable among these artifacts are two large corner-tang knives, one made of gray Georgetown flint.

The increase of Central Texas material in the study area during the Late Archaic is probably the result of several factors. Increasing population and suggested movement into the study area, with a concomitant shift in subsistence strategy to include bison hunting likely produced the influx of San Marcos Phase projectile forms. Likewise, the advent of Late Archaic trade networks undoubtedly contributed to the ditribution of popular tool forms.

Following the early part of the Late Archaic is an hypothesized period of coalescence and greater cultural stability in the study area, comparable to the Twin Sisters Phase (Weir 1976) in Central Texas. Limited evidence of this phenomenon is seen in the development of projectile point styles which occur in significantly greater numbers than any precedent types. At the same 
time there appears to be a decrease in the number of Central Texas projectile points. Furthermore, excavations at several sites have produced evidence of substantial occupation components, exceeding other components in terms of features and artifacts,

Two of the hallmark projectile styles of the Twin Sisters Phase, Frio and Ensor, in the study area are rare in the case of Frio and usually modified in the case of Ensor. Fairland seems to occur in numbers roughly equal to Ensor. The Ensor-like styles of the study area appear to be regional variants of a widespread Late Archaic phenomenon, the side/corner-notched projectile point. Although the Ensor type is ubiquitous across Central Texas and adjacent areas, it is not abundant in the same form in the study area. Therefore, the presence of numerous "Ensor-like" artifacts here should not be considered an expression of Central Texas influence.

Two distinctive forms with deep corner notches/expanding stems are widespread in the study area. The large numbers and wide distribution of these unique forms, in conjunction with an apparent decrease in Central Texas material, strengthen the hypothesis of a developing local cultural tradition.

Perhaps more convincing evidence exists in the form of excavated cultural components dating to this time period. In western Fayette County, at Sites 41FY98 and 41FY422 (Goode 1983, 1984) were found numerous hearths associated with small numbers of Ensor/Fairland-like and Darl artifacts of Late/Transitional Archaic age. Both sites cover extensive areas, and although earlier and later remains are present, these occupations are by far the most intensive.

Further indication of dynamic cultural interaction during this time is seen in the breakdown of the Central Texas trade network established several hundred years earlier. Quoting Hall (1981:303), "Sometime in the period between 50 B.C. and A.D. 200 along the western periphery of the import-export sphere in Texas, pressures were exerted on local populations which triggered the gradual retraction of the sphere. . . " Conflict between Central Texas 
peoples and those inhabiting the study area, resulting in the possible displacement of the latter, is an hypothesized example of population pressure which led to the decline of the import-export sphere (Hall 1981:308).

A $n$ alternate hypothesis, as some evidence would seem to indicate, is that inhabitants of the study area were not exterminated or displaced, but hostilitieses with Central Texas people did halt the flow of trade items. From the Post Oak Savannah region, then, hostilities could have turned eastward into the Allens Creek area, resulting in the deaths of individuals interred at the Ernest Witte Site.

Following the Twin Sisters Phase into the Transitional Archaic or Driftwood Phase (Prewitt 1982) is an apparent continued cultural stability, but with a change in projectile point styles. The primary time marker of this phase/ period, the Darl type, is widespread, occurring in substantial numbers at some sites. The Godley type or something similar is also fairly common in some areas. These types are indigenous to the eastern fringe of Central Texas, which merges with the western portion of the study area, and have been considered to be of Central Texas origin.

The abundance of the Darl type in the study area and the proximity of its known center of distribution indicate that in the study area Darl should be considered a resident type, not an indicator of Central Texas influence. The evidence points to Darl being indigenous to the study area as well as to the eastern fringe of Central Texas.

In summary, the study area is a natural transition zone, separating diverse cultures occupying much greater expanses of territory. The multitude of Archaic projectile point styles present indicates substantial interaction between resident and neighboring cultures. However, the preponderance of diagnostic artifacts cannot be forced into the typologies of Central or East Texas; they evidently should be ascribed to local traditions. 
Recently examined evidence from sites such as 41FY98, 41FY422, 41FY135, and 41BP19 suggests that an indigenous population was settled in the area by Middle Archaic times, probably during the Early Archaic at such sites as 41BP19 and 41FY135. Therefore, the study area is seen as a region which was settled perhaps as early as some neighboring areas.

Normal cultural diffusion from adjacent areas along with possible episodes of population movement produced an abundance of "nonlocal" material in the region. This material, the lack of an established cultural sequence, and the relatively small amount of archaeological investigation have perpetuated the idea that the study area is merely a cultural "transition zone," lacking a definable identity. Future investigation will continue to document that this idea is no longer tenable. 


\section{SITE DESCRIPTION}

Site 41BP19 is located on a prominent point of the uplands overlooking the Colorado River valley to the south (Fig. 1). The south side of the hill is a steep face, dropping $60 \mathrm{ft}$. to the floodplain of Alum Creek. This prominent topographic feature is known as Kennedy Bluffs.

Alum Creek flows 25 meters south of the bluffs, situated in an old channel of the river. A sharp bend of the Colorado River named Hardeman Bend is 300 meters southeast of the site. At this point Alum Creek, a major perennial tributary, intersects the river.

Existing State Highway 71 and the previous roadway bisect the northern portion of the site (Fig. 2). Small amounts of lithic debitage and burned rock are present on the surface north of State Highway 71, but this area is shallow and completely destroyed. The much larger site area south of State Highway 71 originally covered approximately 3 acres. About half of this area is now a gravel pit, excavated to a depth of 3 to 4 meters below ground surface. A smaller area, extending from the northwest edge of the gravel pit to 10 meters east of Test Unit 5 and almost to the old right-of-way fence, has been excavated for topsoil to a depth of $30 \mathrm{to} 40 \mathrm{~cm}$. The remaining site area, averaging 150 by 50 meters, has been cleared and planted in Coastal Bermuda.

A shallow backhoe trench skirts the northern edge of the gravel pit and extends into the broad area south of Test Units 1 and 2. The trench is perhaps 1 meter deep in this area; here was focused the excavations of artifact collectors. Excavation has ceased for about the last two years. A very large number of artifacts was found, many of Early Archaic and Late Paleo-Indian origin.

Cultural material is present from the surface to a depth of $80 \mathrm{~cm}$ in two major soil zones (Fig. 3). The upper zone (Zone 1) is 30 to $40 \mathrm{~cm}$ of fine sandy to silty loam. It contains artifacts of Middle Archaic through 
This Page Redacted Per THC Policy 


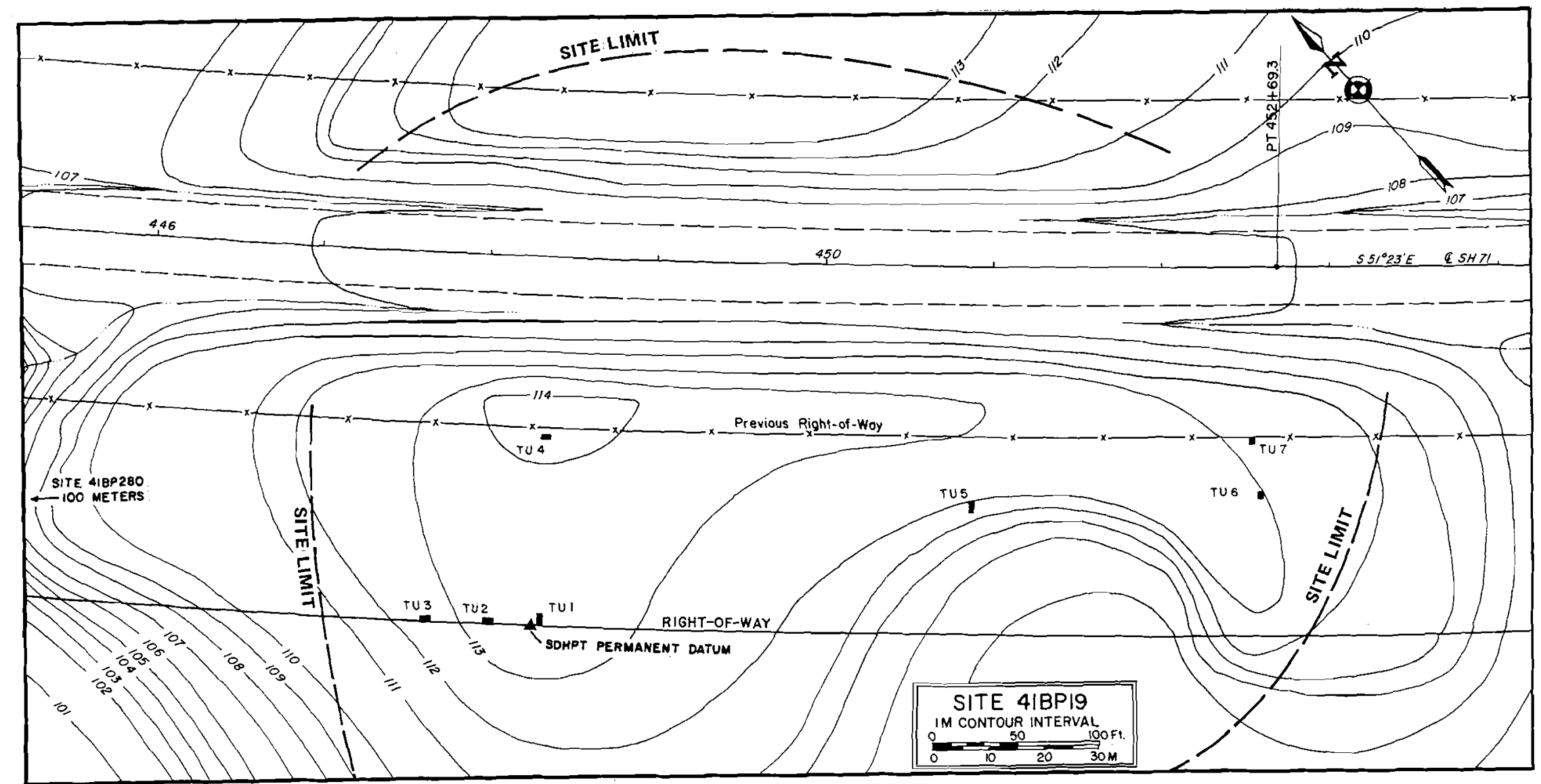

FIGURE 2. Map of site showing excavation units. 


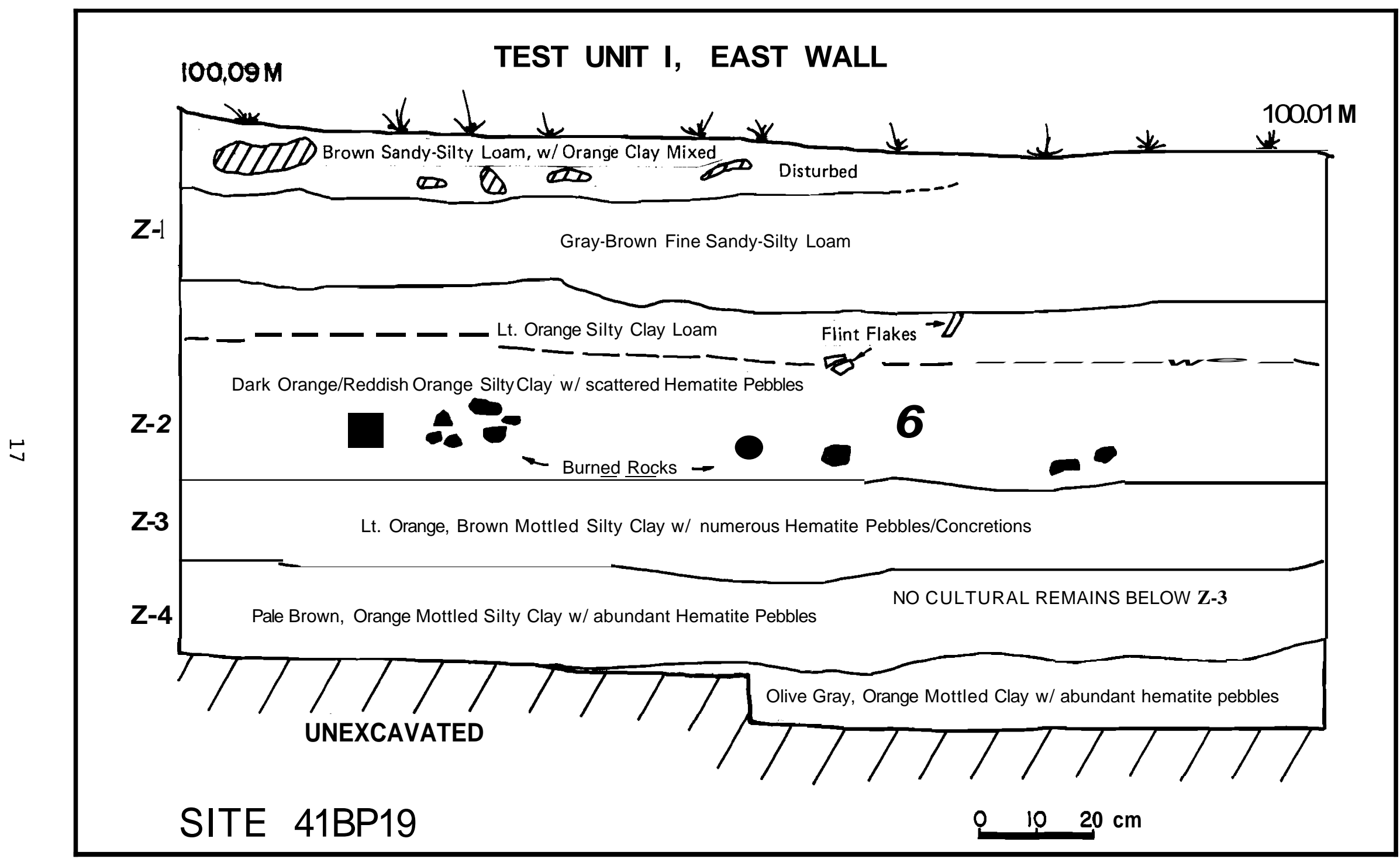

FIGURE 3. East wall profile drawing of Test Unit 1. 
Neo-American or Late Prehistoric age, a period of at least 4000 years. In Zone 1, 1 ithic debitage is abundant and tools are present in moderate numbers. Clear separation of cultural episodes in Zone 1 was not evident. Two burned rock features were found in Zone 1, both just above the Zone 2 clay. Evidence for confidently dating these hearths was not found, but they are possibly Middle Archaic in age--judging by their stratigraphic position.

Zone 2 is 40 to $50 \mathrm{~cm}$ of $\mathrm{silty}$ clay-loam. The silty clay-loam matrix produced numerous artifacts and two burned rock hearths as well. The upper $15 \mathrm{~cm}$ contained abundant lithic debitage but comparatively few recognizable tools. No diagnostic artifacts were found.

A phenomenon associated, stratigraphically at least, with the Zone 2 clay is the patination of a large percentage of lithic materials. A small amount of lithic material in the last level above the clay was patinated; then, the percentage increased considerably in the first level of Zone 2. Perhaps $80 \%$ of the lithic debitage and tools within Zone 2, as well as some burned rocks and unmodified cobbles, is patinated to some degree.

At an average depth of $60 \mathrm{~cm}$ below the ground surface in Test Unit 1 and Test Unit 2, a discrete $10 \mathrm{~cm}$ zone of occupation debris was encountered. Within this zone were four concentrations of burned rock, representing two to four hearths (Feature 1 and Feature 4). Feature 1A, a small, irregularly shaped accumulation, had several tools in association. Precise size and configuration of the other concentrations were not determined due to the limited excavation. One concentration (Feature 4B), which is probably greater than 1 meter in diameter, extends beyond the south right-of-way and could not be pursued.

Also at the level of the hearths were numerous burned rocks scattered across the floor. Lithic debitage at this level decreased to about $25 \%$ 
of the overlying level; however, a large number of tools was present.

In fact, the tool-to-debitage ratio of the occupation zone is significantly greater than that of the overlying levels. Included in the assemblage are dart points, preforms, biface fragments, flake tools, and grinding stone fragments.

A small rockshelter in the south face of the hill is partially collapsed and lacks evidence of human occupation. However, a talus deposit several meters downslope from the shelter attests to repeated occupations. Contained in the talus are mussel shells, bison bone, and lithic debitage.

Massive outcrops of a hematite-gravel conglomerate occur along the perimeter of the hill. Flint and quartzite gravel up to large cobble size is abundant throughout this formation. Much gravel is scattered from this source which must have served as the major supply of lithic material for the aborigines. 


\section{EXCAVATION PROCEDURE}

Seven test units were excavated at Site 41BP19: five 1 by 2 meter and two 1 by 1 meter units (Fig. 2). Four 1 by 2 meter units were placed toward the western end of the site, one in the central area, and two 1 by 1 meter units toward the eastern end.

Units were aligned parallel to the right-of-way fences, but a grid was not established. In the western area three units were placed on the south right-of-way line, nearest the area excavated by artifact collectors. This area appeared to have the deepest undisturbed deposits and greatest potential for producing in situ cultural material.

A n elevation datum designated 100 meters was established on the south right-of-way line. The datum is a hub driven to ground surface 2 meters west of Test Unit 1. A 11 units were excavated in arbitrary $10 \mathrm{~cm}$ levels and the matrix was screened through $1 / 4 \mathrm{in}$. hardware cloth. Due to the extremely hard and dry soil, it was necessary to use picks, as well as shovels and trowels, in some levels. A water truck was used frequently to wet the soil prior to excavation. All cultural material, including burned rock, was bagged at the screen. After artifacts were picked from the burned rock, it was discarded.

The four burned rock features encountered, interpreted as hearths/hearth remnants, were recorded in situ by plan drawings, photographs, and by elevation. Associated artifacts were likewise recorded. 


\section{ARTIFACTS}

A large and varied inventory of artifacts was recovered at Site 41BP19. Five major classes of stone are present: bifaces, unifaces and edgemodified flakes, cores and cobbles (core stock), ground and battered stone, and flakes and chips.

\section{Bifaces}

Bifacial artifacts from the excavations are represented by 45 specimens: 4 arrowpoints, 11 dart points, 1 knife fragment, and 29 unfinished specimens. In addition, 6 specimens, including 1 arrowpoint fragment and 2 dart points, were recovered from the surface.

Arrowpoints (Fig. 4A-C,Q)

One arrowpoint (Fig. 4C) is a concave-based Scallorn, brangus variety. One preform and 2 basal/corner-notched fragments complete the arrowpoint sample. Neither fragment can be confidently identified, but Specimen Q, found on the surface, may be of the Perdiz type.

Dart Points (Fig. 4D-P, Fig. 5C)

No complete dart points were found in the excavation, but 9 fragments and at least 2 preforms are present.

Two specimens represent the transitional Archaic Period. Specimen D is a Darl-like base, and Specimen E is a midsection, perhaps of the same type. It has fine pressure flaking often seen in the Darl type. 
The Late Archaic Period is represented by at least 1 dart point, possibly by 2 or 3 . Specimen $F$ is a large corner-notched variety similar to the Marcos type. This specimen was broken near completion. Specimen H may have been corner-notched and also may be of Late Archaic age. Heat fracture removed a large portion of the base. Specimen N, a surface find, has an expanding stem and concave base, traits common to some Late Archaic types.

Specimens $G$ and I have straight to slightly contracting stems, neither of which is complete. These pieces are likely of Late or Middle Archaic age. The blade of Specimen I has been worked into a narrow form, possibly for use as a drill. Specimen $M$ is a Pedernales dart point of Middle Archaic age. It is a surface find from the edge of the gravel pit.

Two specimens, J and L, Were found in an apparent Early Archaic context with some patina. Specimen $\mathbf{J}$ appears to be a preform for an untyped lanceolate form which is numerous at this site and present at other sites of the area. This type can be called a Form A biface. A large number of Form A bifaces have been found in miscellaneous collectors' excavations 15 to 50 meters south of the right-of-way. Only Specimen $\mathbf{J}$ was found in the SDHPT excavations. The lanceolate outline of Form A bifaces is similar to some Angostura points. Ground edges and bases are common, with bases ranging from slightly concave and straight to slightly convex in some specimens. Excellent thinning of the blade by soft-hammer and pressure flaking is exhibited in some specimens. Many others display only average workmanship, possibly due to the inherent difficulties of working small, rounded cobbles.

Another distinctive type (Form B biface) found in the same area and at the same depth as Form A is also of lanceolate form. The outline is vaguely similar to the Eden type, but no other similarities exist. Square stems with smoothed edges and well pressure-flaked blades are typical. Form B lacks the collateral flaking and diamond cross-section of the Eden type. 
Specimen L is a corner-notched dart point which has been altered by patination and burning. The burning removed a portion of the base and one shoulder. This point could be classified as "Early Corner-Notched/Barbed," and possibly is most closely related to the Martindale type. Specimen L was found beside Feature 4, a burned rock hearth.

Specimen $K$ is a concave base portion of an apparent lanceolate form, possibly of Early Archaic age. If it derives from the Early Archaic, it was found out of context (Level 2).

Specimen $\mathrm{P}$ is a thoroughly patinated lanceolate form which was found along the edge of the gravel pit. Despite edge damage and a thick cross-section produced by resharpening, this piece is clearly related to the early lanceolate forms. It was also coated with the red clay in which the early forms occur.

Knife (Fig. 5F)

One thin biface fragment is the proximal section of a well made knife (Fig. 5F). It has a slightly concave base and the edges are straight. This piece and an arrowpoint fragment (Fig. 4A)were found in Level 1 of Test Unit 7. Other evidence of a Late Prehistoric occupation came from Test Unit 6 located nearby.

Unifaces and Edge-Modified Flakes (Fig. 5A,B,E)

Two hard-hammer flakes have unifacial chipping from two edges. Primary chipping occurs on the distal end of both pieces, producing the relatively steep edge angle typical of scraping tools. At least 30 other specimens have minor edge trimming or modification produced by use. The relatively acute edge angles of these flakes indicate that many were used as cutting tools. 


\section{Cores and Cobbles}

Twenty-nine cores and core fragments and four unaltered chert cobbles, possibly core stock, were found. Some specimens were thoroughly reduced, resulting in small, irregularly shaped core fragments. Others exhibit random to ineffective reduction--typical reduction patterns of the relatively small, rounded cobbles of the area.

Ground and Battered Stone (Fig. 5G)

The ground and battered stone category has 9 specimens. Three quartzite cobbles were used in battering operations, apparently as hammerstones. The largest specimen (Fig. 5GI) has extensive damage in three areas. The ground stone artifacts are fragments of ferruginous sandstone and quartzite cobbles. Some of these wre used as grinding stones.

Flakes and Chips

The flakes and chips are primarily debitage resulting from the manufacture of flint tools. These number approximately 6500 specimens. Flakes from all stages of core, biface, and uniface reduction are present. Primary cortex flakes occur in sufficient numbers to indicate on-site initial reduction of cores and bifaces. Secondary cortex flakes are much more numerous, but a majority of flakes are relatively thin tertiary specimens. Several flakes of $100 \mathrm{~mm}$ in size were found, with a good sample being larger than $50 \mathrm{~mm}$. However, a large majority of flakes/fragments are smaller than $30 \mathbf{m m}$. 


\section{SUMMARY， INTERPRETATIONS, AND RECOMMENDATIONS}

Site 41 BP19 is a multicomponent habitation site located on a hilltop overlooking the Colorado River valley. Originally, aboriginal occupation covered an area of approximately 200 by 200 meters, but about half of the site has been removed by gravel mining and by State Highway 71. Recent digging activities by artifact collectors have destroyed a significant portion of the site as well. Despite the destruction caused by these activities, a combined area of about 150 by 50 meters remains intact, with recent disturbance limited to the upper $20 \mathrm{~cm}$.

Cultural material is present from the surface to a depth of $80 \mathrm{~cm}$ in two major soil zones. The upper zone contains artifacts of Middle Archaic through Neo-American or Late Prehistoric age, a period of at least 4000 years.

At an average depth of $60 \mathrm{~cm}$ below the ground surface a discrete 10 an zone of occupation debris was encountered. Within this zone were burned rock features, a burned rock living surface, and a number of tools. An Early Archaic age is tentatively set for this component, probably dating between 6000 and 8000 years before present. This date is based upon three sets of evidence:

1. Stratigraphic Position. The component, $10 \mathrm{~cm}$ in thickness, is $30 \mathrm{~cm}$ below Middle Archaic material.

2. Diagnostic Artifacts. The corner-notched dart point (Fig. 4L) is an early barbed form. The preform (Fig. 4J) is similar to numerous lanceolate forms found by collectors at this site. The lanceolate point (Fig. 4P) eroded out of lower Zone 2 soil, at relatively the same depth as those specimens in Figure 4J and Figure 4L. 
3. Observations of Artifact Collectors. According to Ralph Yargo (Ralph Yargo, personal communication), the total cultural deposit increases to more than 1 meter in depth south of Test Units 1 and 2. Here, 20 to 25 meters south of the right-ofway, were found numerous lanceolate points lying in the upper few $\mathrm{cm}$ of the Zone 2 orange clay. Also found were several Angostura points and another lanceolate form, possibly PaleoIndian. Hearths were noted with this material, as well as abundant debitage and a variety of tools, representing a major occupation zone or component(s). This occupation zone apparently corresponds with that described in Test Units 1 and 2.

Somewhat deeper in the reddish orange clay were found biface fragments (Fig. 5D) and lithic debitage, but no diagnostic artifacts. This material could very well derive from a Late Paleo-Indian occupation. Similar material, although in small numbers, is present in Test Units 1 through 5.

Site 41 BP19 is undoubtedly one of the most important aboriginal habitation sites in Bastrop County and the surrounding region. The potential exists for significantly increasing knowledge of regional cultural development during the last 8000 to 9000 years. While it appears that some cultural episodes are better represented than others, apparently all Archaic and Late Prehistoric Periods are present. Of particular importance within Zone 1 may be the Late Prehistoric and Middle Archaic occupations. Bison and deer bone, rare in most sites of the area, were found in an apparent Late Prehistoric context (Test Unit 6).

Late Prehistoric material is widespread across the site and includes elements of both the Austin Phase and the Toyah Phase. Perdiz points of the Toyah Phase have been reported from the area south of the right-of-way. Two point fragments from the Test Unit 6 and Test Unit 7 area may also be of Perdiz age. Two hearths, the only features found in Zone $\mathbf{1}$, may be associated with Middle Archaic occupations. Few features of this age 
have been reported in the area and their presence indicates that a substantial occupation may be present.

Within Zone 2, the Early Archaic occupation zone isolated in Levels 5 and 6 is perhaps the most significant cultural component at the site. This status is determined by the discrete nature of the component, the features and tool inventory, and by the great age of the material. Cultural components of Early Archaic and Late Paleo-Indian age occurring in a stratified deposit have not heretofore been systematically excavated in this region of Texas.

Site 41BP19 presents the opportunity to thoroughly examine such a component, thereby making an important contribution of a little known period of Texas prehistory. Moreover, 41BP19 has the potential for contributing knowledge of the succeeding cultural Periods, in many ways as poorly known as the Early Archaic.

The presence of the Early Archaic/Late Paleo-Indian component(s) alone is sufficient reason to recommend 41BP19 for additional excavation. And the existence of abundant later material further strengthens this position. Therefore, 41BP19 is recommended for nomination to the National Register of Historic Places and for further archaeological investigation. 


\section{REFERENCES CITED}

Brown, David O., and Ray D. Kenmotsu

1980 Test Excavations in the Fayette to Lytton Springs Transmission Corridor, Bastrop and Fayette Counties, Texas. Texas Archeological Survey Research Report 77. The University of Texas at Austin.

Fox, Daniel E., Robert J. Mallouf, Nancy O'Malley, and William M. Sorrow 1974 Archeological Resources of the Proposed Cuerol Reservoir, DeWitt and Gonzales Counties, Texas. Texas Historical Commission and Texas Water Development Board. Austin.

Fullem, Bruce B.

1977 The Black Hopper Site. Publications in Archaeology 10. State Department of Highways and Public Transportation, Highway Design Division. Austin.

Goode, Glenn T.

1983 Research Design for the Proposed Excavation of Site 41FY98, Fayette County, Texas. State Department of Highways and Public Transportation, Highway Design Division. Austin.

1984 A Report of Testing at Archaeological Sites 41FY421, 41FY422, 41FY424 in Fayette County, Texas. State Department of Highways and Public Transportation. Austin.

Hall, Grant D.

1981 Allens Creek: A Study in the Cultural Prehistory of the Lower Brazos River Valley, Texas. Texas Archeological Survey Research Report 61. The University of Texas at Austin. 
Hester, Thomas Roy, and Robert C. Parker

1970 The Berclair Site: A Late Prehistoric Component in Goliad County, Southern Texas. Bulletin of the Texas Archeological Society 41:1-23.

Kelley, J. Charles

1955 The Archaic Culture in Central, Southern, and Western Texas. Paper presented at the 1955 Archaic Conference, Indiana University. Bloomington.

Kenmotsu, Ray D., Leland C. Bement, and David G. Rohinson

1982 Cultural Resource Investigations at the Powell Bend Prospect, Bastrop County, Texas. Texas Archeological Survey Research Report 84. The University of Texas at Austin.

Mallouf, Michael G.

1979 Archeological Investigations at Lake Limestone, Fall and Winter Season, 1977. Texas Archeological Survey Research Report 71. The University of Texas a t Austin.

McGuff, Paul R.

1978 Prehistoric Archeological Investigations at Palmetto Bend Reservoir: Phase I, Jackson County, Texas. Texas Archeological Survey Research Report 58. The University of Texas at Austin.

Nightengale, Bruce A., and Jack M. Jackson

1983 Intensive Survey of Cultural Resources in the Cummins Creek Project, Fayette County, Texas. Texas Archeological Survey Research Report 86. The University of Texas at Austin. 
Peterson, Frederick A.

1965 The Erwin's Bridge Site at Somerville Reservoir, Burleson County, Texas. Report submitted to the National Park Service by the Texas Archeological Salvage Project. The University of Texas at Austin.

Prewitt, Elton R.

1974 Upper Navasota Reservoir: An Archeological Assessment. Texas Archeological Survey Research Report 47. The University of Texas at Austin.

1982 Archaeological Investigations at the San Gabriel Reservoir Districts, Central Texas, Volume 4. Institute of Applied Sciences, North Texas State University. Denton.

Skelton, Duford W.

1977 Archeological Investigations at the Fayette Power Project, Fayette County, Texas. Texas Archeological Survey Research Report 60. The University of Texas at Austin.

Skelton, Duford W., and Martha Doty Freeman

1979 A Cultural Resource Inventory and Assessment at Camp Swift, Texas. Texas Archeological Survey Research Report 72. The University of Texas at Austin.

Weir, Frank A.

1976 The Central Texas Archaic. Ph.D. dissertation. Department of Anthropology, Washington State University. Pullman.

Young, Wayne C.

1979 Preliminary Report on the Excavation of 41FY135. Manuscript on file at the Texas State Department of Highways and Public Transportation, Archaeology Section. Austin. 